Eur J Clin Chem Clin Biochem

1995; 33:679-686

(c) 1995 Walter de Gruyter \& Co.

Berlin $\cdot$ New York

\title{
Short-Term and Long-Term-Effects of Phorbol 12-Myristate 13-Acetate and Different Inhibitors on the Ability of Bone Marrow Cells to Form Colonies In Vitro
}

\author{
By Dora Višnjićc ${ }^{1}$, Drago Batinićc ${ }^{2}$, Matko Marušić ${ }^{1}$ and Hrvoje Banfićc \\ 1 Department of Physiology, School of Medicine, University of Zagreb, Zagreb, Croatia \\ 2 Department of Clinical Laboratory Diagnosis, Clinical Hospital Center, Zagreb, Croatia
}

(Received January 23/March 16, 1995)

Summary: The process of signal transduction responsible for the phorbol 12-myristate 13-acetate mediated increase in the colony-forming potential of murine (CBA) bone marrow cells was studied using known modulators of the mitogenic signal. Pretreatment of cells for 60 minutes with staurosporine $(1 \mu \mathrm{mol} / \mathrm{l})$, an inhibitor of protein kinase $\mathrm{C}$, completely prevented colony formation in the control group of cells and significantly reduced the number of colonies formed in the phorbol ester-treated group. Brief exposure $(60 \mathrm{~min})$ of cells to the phospholipase $\mathrm{A}_{2}$ inhibitors, mepacrine $(500 \mu \mathrm{mol} / \mathrm{l})$ and heparin $(1 \mathrm{~g} / \mathrm{l})$, reduced the number of colonies formed in the control group and completely abolished the increase in the number of colonies formed after treatment of the cells with phorbol ester. When inhibitors of protein kinase $C$ or phospholipase $A_{2}$ were present during the entire period of the colony forming assay ( 7 days), no colonies could be scored in either the control or phorbol ester-treated groups of bone marrow cells. Long-term treatment or temporary exposure $(60 \mathrm{~min})$ of cells to indomethacin $(50 \mu \mathrm{mol} / \mathrm{l})$, an inhibitor of cyclooxygenase, or nordihydroguaiaretic acid $(50 \mu \mathrm{mol} / \mathrm{l})$, an inhibitor of lipoxygenase, had no effect on colony formation in both groups. Pretreatment of cells for $45 \mathrm{~min}$ with calcium ionophore A23187 (10 $\mu \mathrm{mol} / \mathrm{l})$ failed to increase the number of colonies, compared with the control group. Moreover, simultaneous treatment of cells for $45 \mathrm{~min}$ with phorbol ester $(500 \mathrm{nmol} / \mathrm{l})$ and $\mathrm{A} 23187(10 \mu \mathrm{mol} / \mathrm{l})$ did not produce any further increase in the number of colonies, compared with the phorbol ester-treated group, suggesting that elevation of intracellular calcium is unimportant in the phorbol ester-mediated response. Dibutyryl cyclic adenosine monophosphate $(50 \mu \mathrm{mol} / \mathrm{l})$ in the presence or absence of phorbol ester, failed to stimulate colony formation, indicating that cyclic AMP-dependent protein kinases are not involved in the signalling process. Temporary exposure $(75 \mathrm{~min})$ of bone marrow cells to okadaic acid $(1 \mu \mathrm{mol} / \mathrm{l})$, a potent inhibitor of serine/ threonine phosphatases, or to tyrphostine AG-115 $(20 \mu \mathrm{mol} / \mathrm{l})$, a tyrosine kinase inhibitor, did not effect colony growth in the control or phorbol ester-treated group. The results indicate that phospholipase $A_{2}$ activation is involved in the phorbol ester-mediated increase in colony formation, since, of the different agents applied, only staurosporine, an inhibitor of protein kinase $\mathrm{C}$, and mepacrine and heparin, putative inhibitors of phospholipase $A_{2}$, were capable of abolishing phorbol ester-mediated effects.

\section{Introduction}

Haematopoiesis provides an example of a precisely regulated hierarchical system in which multipotential stem cells continuously produce mature blood cells via a series of progressively lineage-restricted progenitor cell populations. Using specific colony stimulating factors, committed progenitor cells of every major haemopoietic class can be induced to proliferate in agar cultures and to generate colonies of differentiating progeny cells. Although many of these haematopoietic growth factors have now been purified to homogeneity and their genes 
cloned, postreceptor signalling events elicited by the occupation of their respective receptors are only partially described $(1,2)$.

Phorbol 12-myristate 13-acetate has been found to induce some myeloid leukaemic cells to differentiate along the monocyte-macrophage pathway (3), and to modulate the in vitro proliferation and differentiation of normal erythroid and granulocytic-monocytic progenitor cells $(4,5)$. Phorbol esters exert their effects on cellular function by activating protein kinase $\mathrm{C}$, a family of calcium, phospholipid-dependent protein kinases, which are also activated by some haematopoietic cytokines. This model has therefore proved useful for determining the role of protein kinase $C$ in the growth, development and lineage commitment of haematopoietic progenitor cells (6).

Our previous study (7) focused on the downstream effects of the phorbol ester-mediated activation of protein kinase $C$ in bone marrow cells. The results showed the phorbol ester increased particulate phospholipase $\mathrm{A}_{2}$ activity and that this effect was abolished by pretreatment of cells with mepacrine and heparin. Phorbol ester did not influence $\left[\mathrm{Ca}^{2+}\right]_{\mathrm{i}}$ homeostasis, phospholipase $\mathrm{C}$ or phospholipase D activity, or the concentration of cAMP, despite the existence of systems, including leukaemic haematopoietic cells, where 'crosstalk' between these signalling pathways has been shown to be modulated by protein kinase $C(6,8)$. Treatment of cells with phorbol ester increased the amount of membrane bound $\alpha, \beta, \delta$, $\varepsilon$, and $\zeta$ isoforms. Pretreatment with mepacrine and heparin reduced the amount of membrane bound protein kinase $\mathrm{C}-\zeta$ in unstimulated cells and diminished the phorbol ester-induced translocation of protein kinase $C-\zeta$ to the membranes without affecting other protein kinase $\mathrm{C}$ isoforms. In conclusion, our previous study suggested that in bone marrow cells the phorbol ester-mediated activation of conventional and novel protein kinases $C$ led to phospholipase $A_{2}$ activation which in turn affects protein kinase $\mathrm{C}-\zeta$. This signalling pathway appears to be mitogenic for bone marrow cells, since inhibition of protein kinases $\mathrm{C}$ by staurosporine, or inhibition of phospholipase $A_{2}$ by heparin and mepacrine diminishes the ability of bone marrow cells to form colonies in vitro (7).

The present study concerns the short- and long-term effects of agents, known to be involved in the modulation of the mitogenic signal (9), on the transduction pathway responsible for increased colony formation after the preincubation of cells with phorbol ester.

\section{Materials and Methods}

Materials and animals

Reagents were obtained from the following sources: Iscove's modified Dulbecco's medium (IMDM), phorbol ester, $4 \alpha$-phorbol ester,
A23187, mepacrine, heparin, nordihydroguaiaretic acid, staurosporine, dibutyryl-cAMP, okadaic acid from Sigma, St. Louis, MO, U. S. A.; foetal calf serum from Gibco BRL, Paisley, U.K.; pokeweed mitogen from Flow in vitro diagnostics, Hemel Hempstead, U. K.; MethoCult M3430 from Stemcell Technologies, Vancouver, BC, Canada. Tyrphostine AG-115 was kindly provided by Dr. $A$. Levitzki. All other chemicals were of analytical grade. All studies were performed on CBA mice of both sexes bred at the Department of Physiology, School of Medicine, University of Zagreb, Croatia.

\section{Isolation of bone marrow cells}

Bone marrow cells from 8-12 week-old CBA mice were obtained by flushing the femoral and tibial shafts with ice-cold Iscove's modified Dulbecco's medium; cell concentration was adjusted to $2-3 \times 10^{9} / 1$.

\section{Colony-forming assay}

Isolated cells $\left(2-3 \times 10^{6} / 1\right)$ were incubated at $37^{\circ} \mathrm{C}$ with phorbol ester and/or different inhibitors. Cells were washed and resuspended, and the concentration was adjusted to $1 \times 10^{9} / 1$; an aliquot $(0.1 \mathrm{ml})$ of this suspension was mixed with $1 \mathrm{ml}$ of MethoCult M3430. Methylcellulose cell-suspensions were equally divided between two 24 well-plates. After 7 days incubation at $37^{\circ} \mathrm{C}$ in a humidified atmosphere of $5 \% \mathrm{CO}_{2}$ in air, discrete cellular aggregates of $>50$ cells were scored as colonies, using an inverted microscope at $25 \times$ magnification. To assess the ability of phorbol ester to promote colony formation in the absence of colony-stimulating factors, bone marrow cells were plated in $0.9 \%$ methylcellulose in Iscove's modified DMEM containing $20 \%$ foetal calf serum with or without $20 \%$ pokeweed mitogen spleen conditioned medium.

Pokeweed mitogen spleen conditioned medium

Media conditioned by splenocytes in the presence of pokeweedmitogen was made according to methods previously described (10). Briefly, splenocyte suspensions form the CBA mice were incubated at a cell concentration of $5 \times 10^{9} / \mathrm{A}$ in Iscove's medium containing $20 \%$ foetal calf serum and $5 \mathrm{mg} / \mathrm{l}$ pokeweed mitogen. After seven days incubation at $37^{\circ} \mathrm{C}, 5 \% \mathrm{CO}_{2}$, the supernatant was removed, centrifuged at $550 \mathrm{~g}$ for 10 minutes, passed through a $0.22 \mu \mathrm{m}$ filter, and stored at $-20^{\circ} \mathrm{C}$ until use. Each preparation of pokeweed mitogen spleen conditioned medium was tested in methylcellulose-based assay for murine colony formation.

\section{Statistical evaluation}

The data are shown as means \pm S.E.M. For statistical analyses Student's $t$ test for unpaired samples at the level of significance of 0.05 was used.

\section{Results}

Unseparated bone marrow cells form colonies in the M3430 conditioned medium after 7 days of incubation. Although provided with an optimal level of colony stimulating factors, cells could be induced to form significantly more colonies by stimulation with phorbol ester. Brief (45 min) exposure of bone marrow cells to phorbol ester $(5-500 \mathrm{nmol} / \mathrm{l})$ caused dose-dependent stimulation of colony formation (results not shown). In order to investigate the effect of phorbol ester on unseparated bone 
marrow cells in the absence of colony-stimulating factors, cells were plated without added sources of colony stimulating activity. In the absence of pokeweed mitogen spleen conditioned medium, colony formation was not observed. When the cells were grown in the methylcellulose colony forming assay in the presence of phorbol ester $(500 \mathrm{nmol} / \mathrm{l})$ alone, no colonies were seen at either 7 or 14 days of incubation. In the presence of pokeweed mitogen spleen conditioned medium, phorbol ester $(500 \mathrm{nmol} / \mathrm{l})$ caused a significant increase in the number of colonies (results not shown), similar to those observed in the M3430 conditioned medium.

Temporary exposure (45 $\mathrm{min}$ ) of marrow cells to phorbol ester $(500 \mathrm{nmol} / \mathrm{l})$, followed by repeated centrifugations and resuspensions in fresh culture medium, was sufficient to produce a stimulation of colonies comparable to that observed after continuous exposure to the same concentration of phorbol ester (figs. 1 and $3)$. Brief ( $45 \mathrm{~min}$ ) preincubation of bone marrow cells with $4 \alpha$-phorbol ester $(500 \mathrm{nmol} / \mathrm{l})$, an inactive analogue of phorbol ester, did not influence the number of colonies formed, compared with control cells (fig. 1). On the other hand, brief exposure of bone marrow cells to staurosporine $(1 \mu \mathrm{mol})$, an inhibitor of protein kinase C (11), completely prevented colony formation in the control group of cells and significantly reduced the number of colonies formed in the phorbol estertreated group (fig. 1). When staurosporine $(1 \mu \mathrm{mol} / \mathrm{l})$ was present during the entire period of the colony forming assay ( 7 days), no colonies could be scored in both groups (fig. 3).

Our previous study demonstrated clearly that phorbol ester $(500 \mathrm{nmol} / \mathrm{l})$ increased particulate phospholipase $\mathrm{A}_{2}$ activity, formation of lyso-phosphatidylcholine and arachidonic acid release in bone marrow cells. These effects were abolished by pretreatment of the cells with the combination of putative phospholipase $A_{2}$ inhibitors. When applied together, mepacrine $(500 \mu \mathrm{mol} / 1)$ and heparin $(1 \mathrm{~g} / \mathrm{l})$, inhibited more than $80 \%$ of initially measured particulate phospholipase $\mathrm{A}_{2}$ activity in untreated cells. While indomethacin $(50 \mu \mathrm{mol} / \mathrm{l})$ and nordihydroguaiaretic acid $(50 \mu \mathrm{mol} / \mathrm{l})$ inhibited the cyclooxygenase or lipoxygenase pathway, respectively, of arachidonic acid metabolism (as measured by their products, prostaglandin $\mathrm{E}_{2}$ and leukotriene $\mathrm{B}_{4}$ ), they did not influence phorbol ester-mediated phospholipase $A_{2}$ activation or translocation of protein kinase $\mathrm{C}$ from the soluble to particulate fraction (7). As shown in figure 2, brief exposure of cells to phospholipase $A_{2}$ inhibitors reduced the number of colonies formed in the control group and completely abolished the increase in the number of colonies formed after treatment with phorbol ester. When inhibitors were present during the entire period of the colony forming assay ( 7 days), no colonies could be

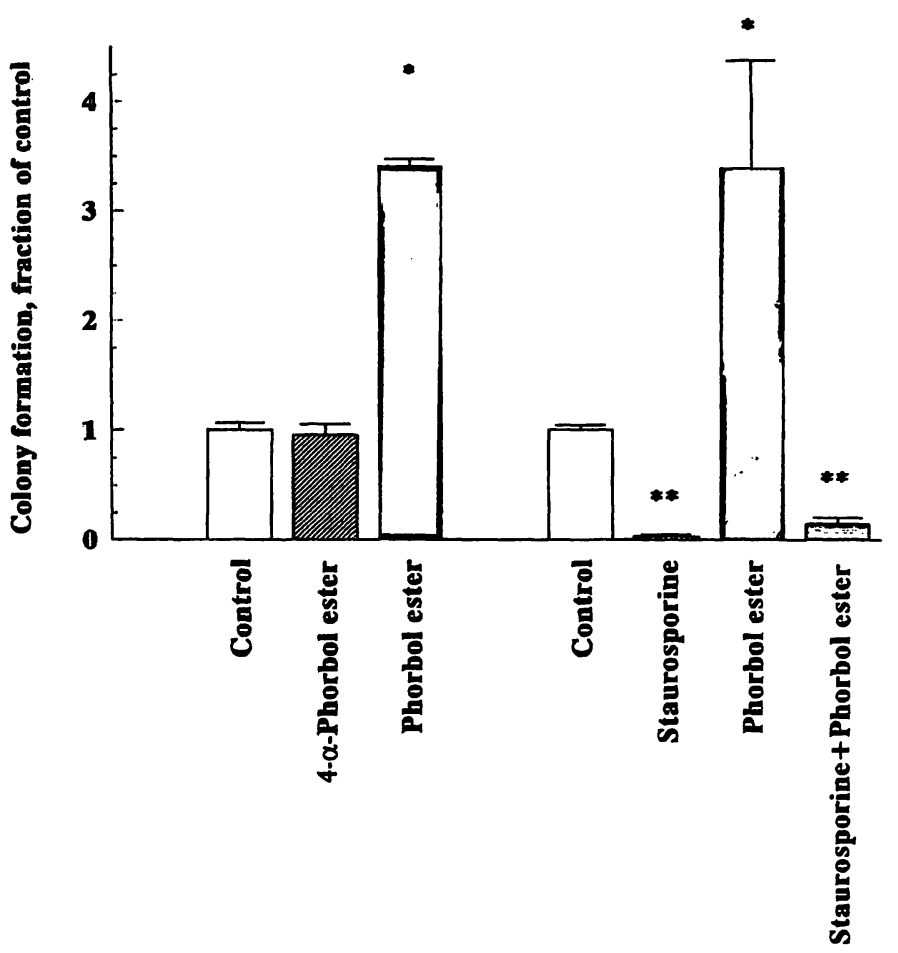

Fig. 1 The effect of short-term exposure of murine bone marrow to phorbol ester, $4 \alpha$-phorbol ester and staurosporine on colony formation. Bone marrow cells were treated for $45 \mathrm{~min}$ with phorbol ester $(500 \mathrm{nmol} / \mathrm{l})$ and $4 \alpha$-phorbol ester $(500 \mathrm{nmol} / \mathrm{l})$ and for 60 min with staurosporine $(1 \mu \mathrm{mol} / \mathrm{l})$. A group of cells was pretreated for $15 \mathrm{~min}$ with staurosporine $(1 \mu \mathrm{mol} / 1)$ and then stimulated with phorbol ester $(500 \mathrm{nmol} / \mathrm{l})$ for $45 \mathrm{~min}$. After the preincubation, the cells were washed and plated as described in the Materials and Methods. After 7 days incubation the number of colonies scored in control wells varied from 20 to 75 (mean value $42 \pm 6$, the number of cell preparations $=7$ ). Results are expressed as a percentage of the number of colonies formed by control cells in the Methocult M3430 conditioned medium and are the mean \pm S. E. M. of at least three different experiments performed in duplicate.

* Statistically significant difference $(\mathrm{P}<0.05$, Student's $\mathrm{t}$ test) from control.

** Statistically significant difference from phorbol ester-treated.

scored in either control or phorbol ester-treated groups of bone marrow cells (fig. 3). Temporary exposure $(60 \mathrm{~min})$ of cells to indomethacin $(50 \mu \mathrm{mol} / \mathrm{l})$ or nordihydroguaiaretic acid $(50 \mu \mathrm{mol} / \mathrm{l})$ had no effect on colony formation (fig. 2). Long-term treatment of cells with either cyclooxygenase or lipoxygenase inhibitors did not influence the ability of bone marrow cells to form colonies in vitro in both control and phorbol ester-treated groups (fig. 3).

Our previous study ruled out the possible involvement of the cAMP/protein kinase A system in phorbol estermediated signalling in bone marrow cells, because no increase in the level of cAMP was observed when cells were treated with phorbol ester (7). To test the possible effect of dibutyryl-cAMP on control cells or the possible synergistic effect with phorbol ester, cells were exposed for $45 \mathrm{~min}$ to the combination of dibutyryl-cAMP (50 $\mu \mathrm{mol} / \mathrm{l})$ and phorbol ester $(500 \mathrm{nmol} / \mathrm{l})$, or to dibutyryl- 


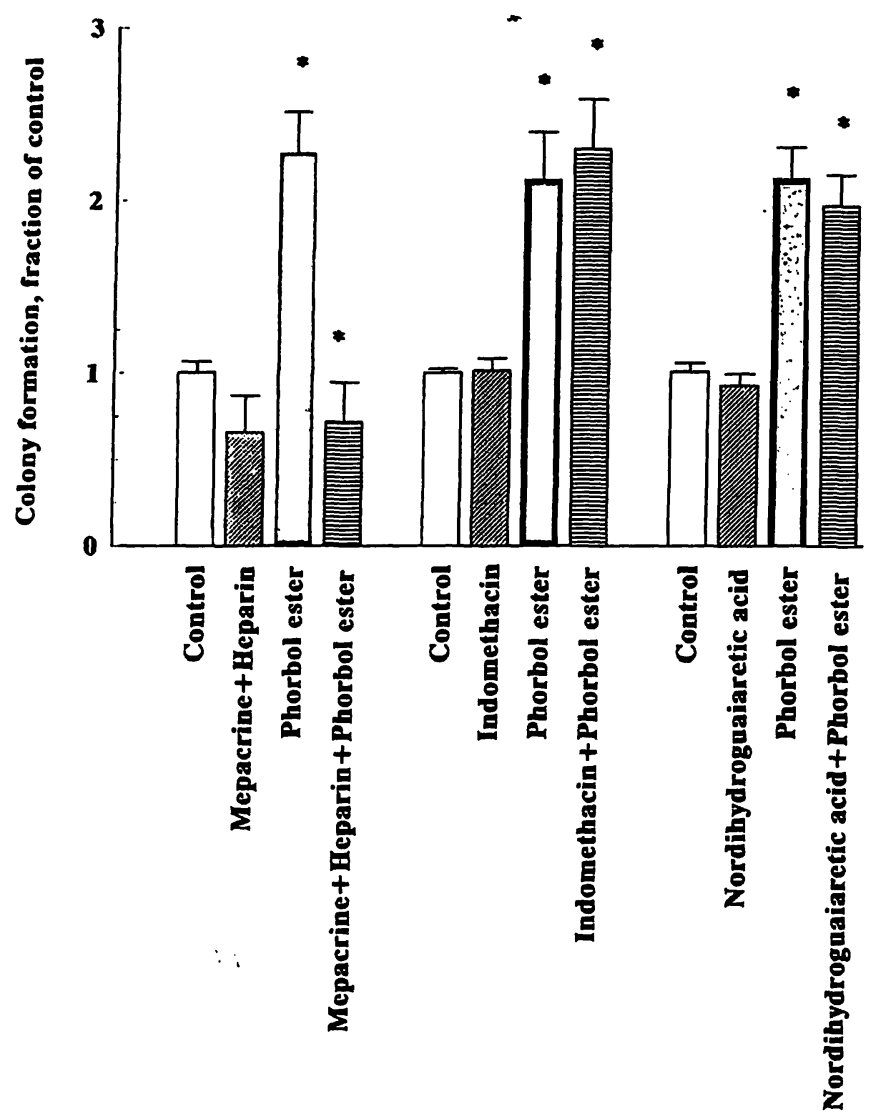

Fig. 2 The effect of short-term exposure of murine bone marrow cells to different inhibitors on colony formation by control and phorbol ester-stimulated cells. Bone marrow cells were treated for $45 \mathrm{~min}$ with phorbol ester $(500 \mathrm{nmol} / \mathrm{l})$, for $60 \mathrm{~min}$ with mepacrine $(500 \mu \mathrm{mol} / 1)$ plus heparin $(1 \mathrm{~g} / \mathrm{l})$, or with indomethacin $(50 \mu \mathrm{mol} / \mathrm{l})$, or with nordihydroguaiaretic acid $(50 \mu \mathrm{mol} / \mathrm{l})$. Other bone marrow cells were pretreated for $15 \mathrm{~min}$ with mepacrine $(500 \mu \mathrm{mol} / \mathrm{l})$ plus heparin $(1 \mathrm{~g} / \mathrm{l})$, or with indomethacin $(50 \mu \mathrm{mol} / \mathrm{l})$, or with nordihydroguaiaretic acid $(50 \mu \mathrm{mol} / \mathrm{l})$, then stimulated with phorbol ester $(500 \mathrm{nmol} / \mathrm{l})$ for $45 \mathrm{~min}$. After 7 days incubation the number of colonies scored in control wells varied from 18 to 151 (mean value $59 \pm 10$, the number of cell preparations $=10$ ). All other details are as described in Materials and Methods and the legend to the figure 1 .

cAMP $(50 \mu \mathrm{mol} / \mathrm{l})$ alone. No effects of dibutyryl-cAMP ( $50 \mu \mathrm{mol} / \mathrm{l})$ were seen on the colony-forming ability of control bone marrow cells or cells stimulated with phorbol ester (500 nmol/l) (fig. 4).

The intracellular signals triggered by inositol trisphosphate and diacylglycerol can be independently mimicked by calcium ionophores (such as A23187) and phorbol ester, respectively. A23187 causes an increase in intracellular $\mathrm{Ca}^{2+}$ and phorbol ester; although it does not provoke a significant increase in $\mathrm{Ca}^{2+}$ it increases the affinity of protein kinase $\mathrm{C}$ for calcium (8). We have previously shown that treatment of unseparated murine bone marrow cells with phorbol ester $(500 \mathrm{nmol} / \mathrm{l}) \mathrm{did}$ not result in any significant increase in the concentration of intracellular calcium over a period of $45 \mathrm{~min}$ (7). To explore the possibility of synergism between phorbol ester and A23187 in increasing the colony-forming ability of bone marrow cells, cells were simultaneously treated for $45 \mathrm{~min}$ with phorbol ester $(500 \mathrm{nmol} / \mathrm{l})$ and A23187 $(10 \mu \mathrm{mol} / \mathrm{l})$. As shown in figure 4 , the treatment of cells with the combination of agents mentioned above did not cause any further increase in the number of colonies. Furthermore, there were no differences in the number of colonies formed by control cells or cells stimulated for $45 \mathrm{~min}$ ionophore alone (fig. 4).

Pretreatment of cells for $75 \mathrm{~min}$ with tyrphostine AG$115(20 \mu \mathrm{mol} / \mathrm{l})$, a tyrosine kinase inhibitor (12), had no effect on the colony-forming potential of either control or phorbol ester-stimulated cells (fig. 4). Temporary exposure $(75 \mathrm{~min}$ ) of bone marrow cells to okadaic acid $(1 \mu \mathrm{mol} / \mathrm{l})$, a potent inhibitor of serine/threonine phosphatases (13), did not effect colony growth in either the control or phorbol ester-treated group (fig. 4).

\section{Discussion}

Short-term (45 min) exposure of unseparated bone marrow cells to $500 \mathrm{nmol} / \mathrm{l}$ phorbol ester, as well as continuous exposure to the same concentration of phorbol ester, significantly increased the number of colonies formed in the M3430 conditioned medium. However, the growth of granulocyte-macrophage colonies was completely dependent on the presence of colony stimulating factors, since no colony formation was observed in the presence of phorbol ester alone. Although previous results suggested that a limited degree of cell proliferation can be promoted by protein kinase $\mathrm{C}$ activation, the proliferative response is not maintained over the several cell divisions required for colony formation (14).

The ability of the phorbol esters to promote colony formation was tested on the unfractionated bone marrow which is composed mainly of mature, accessory cells with only a minor proportion of committed progenitor cells. Therefore, the effect of phorbol ester may be attributable, at least in part, to the ability of protein kinase $\mathrm{C}$ activators to stimulate the production of colony-stimulating factors from accessory cells, such as fibroblasts and macrophages $(15,16)$. However, the results of studies done in the presence of neutralising antibodies to colony-stimulating factors, or on highly enriched population of granulocyte/macrophage colony-forming cells, are compatible with a direct mode of action of phorbol ester on progenitor cells $(14,17)$. In our study, phorbol ester-mediated stimulation of colony formation under conditions which have already provided cells with an optimal level of cytokines could not be ascribed merely to the stimulation of colony-stimulating factor production by accessory cells. It seems much more likely that phorbol ester-mediated activation of protein kinase 


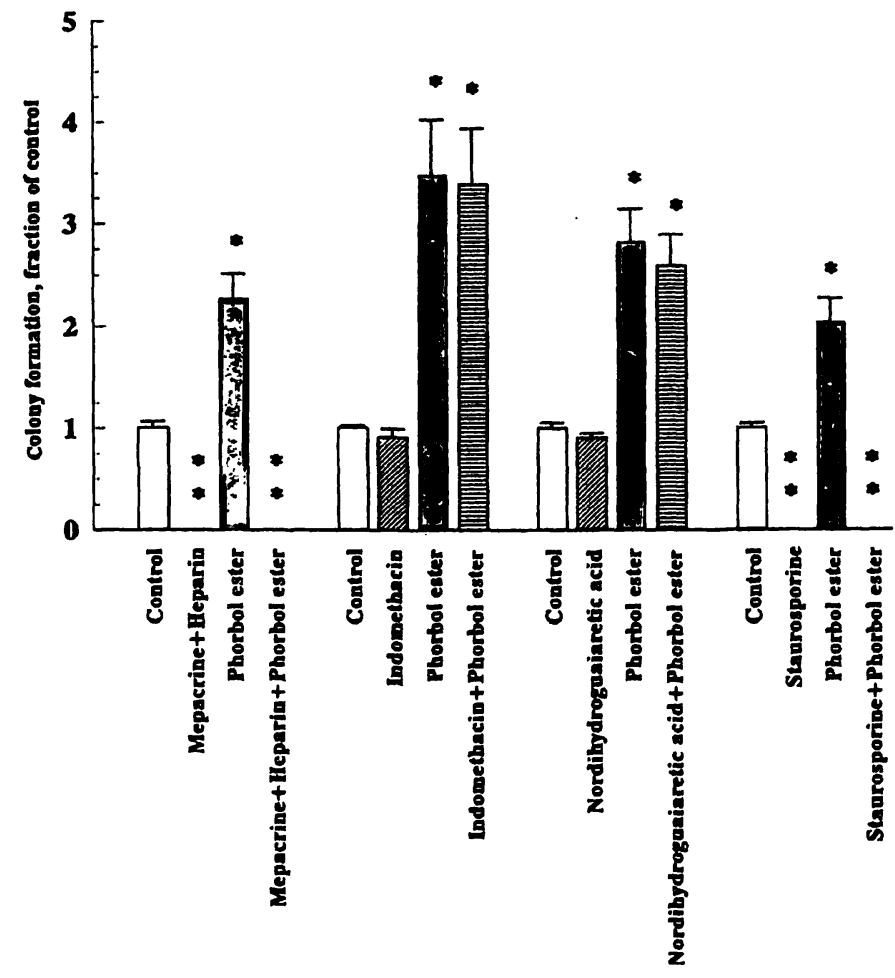

Fig. 3 The effect of long-term exposure of murine bone marrow cells to different inhibitors on colony formation by control and phorbol ester-stimulated cells. Bone marrow cells were treated for $45 \mathrm{~min}$ with phorbol ester $(500 \mathrm{nmol} / \mathrm{l})$, for $60 \mathrm{~min}$ with mepacrine $(500 \mu \mathrm{mol} / \mathrm{l})$ plus heparin $(1 \mathrm{~g} / \mathrm{l})$, or with indomethacin $(50 \mu \mathrm{mol} / \mathrm{l})$, or with nordihydroguaiaretic acid $(50 \mu \mathrm{mol} / \mathrm{l})$. Other bone marrow cells were pretreated for $15 \mathrm{~min}$ with mepacrine $(500 \mu \mathrm{mol} / \mathrm{l})$ plus heparin $(1 \mathrm{~g} / \mathrm{l})$, or with indomethacin $(50 \mu \mathrm{mol} /)$, or with nor-dihydroguaiaretic acid $(50 \mu \mathrm{mol} / \mathrm{l})$, then stimulated with phorbol ester $(500 \mathrm{nmol} / \mathrm{l})$ for $45 \mathrm{~min}$. After incubation, cells were washed, mixed with Methocult 3430 and the agents were added in concentrations equal to those used during pretreatment. After 7 days incubation the number of colonies scored in control wells varied from 18 to 151 (mean value $57 \pm 9$, the number of cell preparations =13). All other details are as described in Materials and Methods and the legend to the figure 1 .

$\mathrm{C}$ acts by permitting an otherwise unresponsive subpopulation of progenitor cells to form colonies in response to these cytokines.

The growth and development of colonies in semisolid cultures involve several processes dependent on the presence of growth factors; survival or prevention of apoptosis, proliferation, irreversible commitment of multipotential progenitors to individual lineages and terminal differentiation into mature blood cells $(1,2)$. In this respect, it has been previously demonstrated that protein kinase $\mathrm{C}$ can influence the commitment of myeloid progenitor cells, leading to macrophage development. A highly enriched population of murine granulocyte/macrophage colony-forming cells was stimulated with an optimal level of interleukin-6 or granulocyte colony-stimulating factor, which are factors with relatively poor colony-stimulating activity on granulocyte/ macrophage colony-forming cells. In such cell popula-

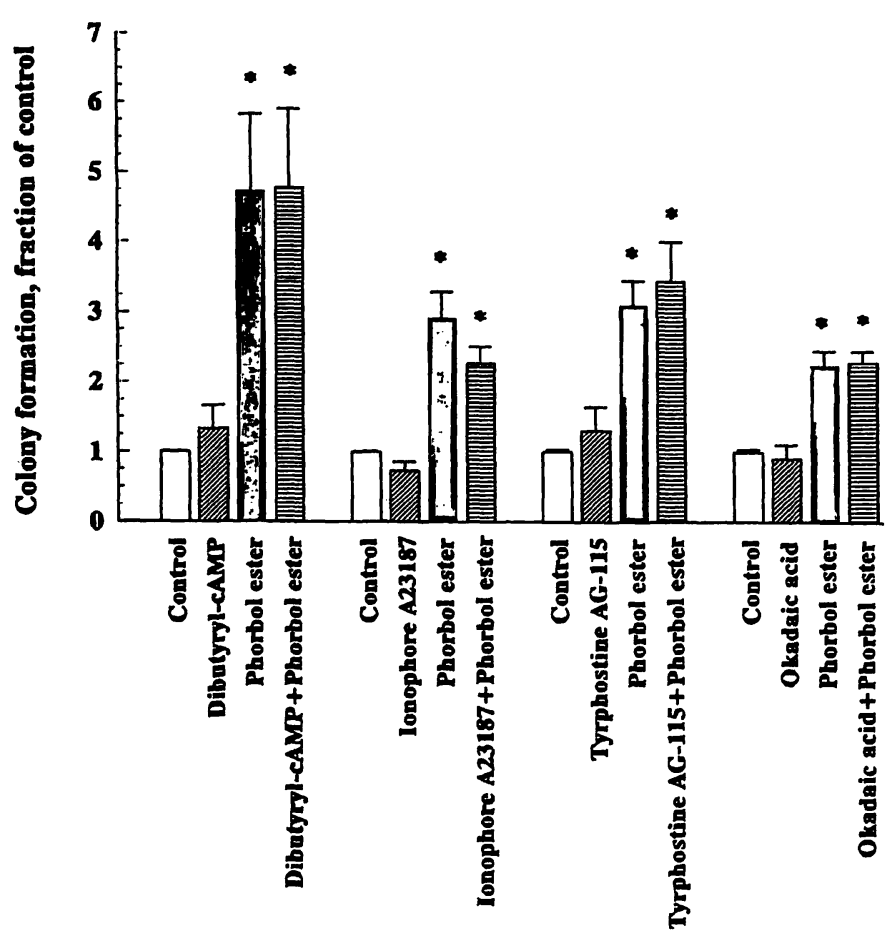

Fig. 4 The effect of short-term exposure of murine bone marrow cells to dibutyryl-cAMP, A23187, tyrphostine AG-115 and okadaic acid on colony formation by control and phorbol ester-stimulated cells. Bone marrow cells were treated for $45 \mathrm{~min}$ with phorbol ester (500 nmol/1), dibutyryl-cAMP $(50 \mu \mathrm{mol} / \mathrm{l})$, or A23187 $(10 \mu \mathrm{mol} / \mathrm{l})$ and for $75 \mathrm{~min}$ with tyrphostine AG-115 $(20 \mu \mathrm{mol} / \mathrm{l})$ or okadaic acid $(1 \mu \mathrm{mol} / \mathrm{l})$. The effects of agents on phorbol ester-stimulated cells were tested by pretreating cells for $30 \mathrm{~min}$ with tyrphostine AG-115 $(20 \mu \mathrm{mol} / \mathrm{l})$ or with okadaic acid $(1 \mu \mathrm{mol} / \mathrm{l})$, then stimulating with phorbol ester $(500 \mathrm{nmol} / \mathrm{l})$ for $45 \mathrm{~min}$. Dibutyryl-CAMP $(50 \mu \mathrm{mol} / \mathrm{l})$ and A23187 $(10 \mu \mathrm{mol} / \mathrm{l})$ were added to cells with 500 $\mathrm{nmol} / 1$ phorbol ester for $45 \mathrm{~min}$. After the preincubation, the cells were washed and plated as described in Materials and Methods. After 7 days incubation the number of colonies scored in control wells varied from 19 to 86 (mean value $52 \pm 4$, the number of cell preparations $=12$ ). All other details are as described in the legend to the figure 1 .

tions, phorbol ester markedly elevated the number of colonies, and altered the types of mature cells from mature neutrophilic cells to a mixture consisting predominantly of macrophages (14). The activation of protein kinase $C$ is involved in transduction of signals initiated by macrophage colony-stimulating factor, interleukin-3 and granulocyte/macrophage colony-stimulating factor, while there is no evidence to suggest that stem cell factor or granulocyte colony-stimulating factor, which are responsible for neutrophil development, can activate protein kinase $C(18,20)$. There may therefore be an important role for protein kinase $\mathrm{C}$ in commitment and lineage restriction decisions in a population of progenitor cells $(14,20)$.

Phorbol ester can also induce cells from various leukaemic cells lines (HL-60, U937) to mature into non-dividing macrophage-like cells, and studies on signalling process responsible for phorbol ester-mediated differentia- 
tion have observed the activation of cytosolic phospholipase $A_{2}$ and the concomitant release of arachidonic acid (21). The results from our previous studies confirmed the importance of phospholipase $\mathrm{A}_{2}$ activation for phorbol ester-mediated increase in colony formation, since inhibitors of phospholipase $A_{2}$ were as effective as staurosporine in inhibiting the phorbol ester-mediated effects on colony formation. Furthermore, the continuous exposure to inhibitors completely prevented colony formation in both control and phorbol ester-treated groups. Despite observations that arachidonic acid metabolites play numerous roles in the regulation of haematopoiesis, neither the short-term nor long-term exposure of cells to indomethacin and nordihydroguaiaretic acid have effects on the colony growth of control or phorbol ester-stimulated cells (figs. 2 and 4). Arachidonic acid metabolites, such as prostaglandin $\mathrm{E}_{2}\left(\mathrm{PGE}_{2}\right)$, mono-hydroxyeicosatetraenoic acid and leukotrienes, have been implicated in the modulation of the colony formation of both erythroid and myeloid progenitor cells and in differentiation processes of leukaemic cell lines (22). Both stimulatory and inhibitory effects of prostaglandins $\mathrm{E}$ and leukotrienes have been observed, depending on the incubation techniques, types and concentrations of colony-stimulating factors and different, and sometimes unphysiologically high, concentrations of agents used $(22-24)$.

Tyrosine phosphorylation is a crucial signal in the transduction of the mitogenic message delivered by the majority of haematopoietic cytokines and precedes the activation of phospholipase $\mathrm{C}$ and the subsequent production of diacylglycerol and activation of protein kinase $C$. All the members of the large haematopoietic cytokine receptor superfamily belong either to a group of receptors with intrinsic tyrosine-kinase activity or recruit one of the cytosolic tyrosine kinases which might in turn activate phospholipase C- $\gamma$ (9). Tyrphostins are the large family of synthetic tyrosine kinase inhibitors expressing high specificity toward cell lines (25), and requiring an extended period of incubation (even hours) to achieve maximal inhibitory effect (26). Somogyi et al. (12) previously showed that tyrphostine AG-115 was effective in inhibiting the activity of cytoplasmic tyrosine kinases associated with the integrin receptor. In the present study, we have ruled out the possible involvement of tyrosine phosphorylation in signalling process responsible for increased colony formation after the short-term preincubation of cells with phorbol ester. Although protein kinase $C$ is one of the major mediators of signals generated when haematopoietic cytokines bind to their receptors, phorbol ester-mediated activation of protein kinase $\mathrm{C}$ obviously by-passes early signalling processes initiated after binding of physiological regulators of proliferation and differentiation. For downstream effects of activated protein kinase $\mathrm{C}$, tyrosine phosphorylation seems not to be crucial.

The short-term pretreatment of bone marrow cells with okadaic acid $(1 \mu \mathrm{mol} / \mathrm{l})$ had no effect on colony formation. The concentration used is well within the range shown by other investigators to exert maximal effects on various cell lines (27-29), including the inhibition of proliferation in leukaemic HL-60 and U927 lines (30). Okadaic acid is a potent inhibitor of protein phosphatases $2 \mathrm{~A}$ and 1, two of the four major protein phosphatases in the cytosol of eukaryotic cells that dephosphorylate phosphoserine and phosphothreonine residues. Because substrates of protein kinase $C$ are primarily dephosphorylated by phosphatases 1 and $2 \mathrm{~A}$, the effects of okadaic acid could reflect the existence of constitutively active protein kinase $\mathrm{C}$. Although phorbol ester and okadaic acid have similar effects on intracellular $\mathrm{pH}$ in rat thymic lymphocytes (27) or the level of epidermal growth factor (EGF)-receptor phosphorylation (28), the substrates or signalling pathways are not necesșarily identical. Okadaic acid was found to enhance the stimulatory effects of phorbol ester on phosphatidylcholine synthesis in NIH 3T3 fibroblasts, but the effect was observed only with suboptimal concentrations of phorbol ester (29).

We have previously shown that the phorbol ester-stimulation of bone marrow cells was not associated with the elevation of cAMP. To further elucidate the role of cAMP and protein kinase A on phorbol ester-mediated signalling, we investigated the effects of short-time exposure of bone marrow cells to $50 \mu \mathrm{mol} / 1$ dibutyrylcAMP, an agent that mimicks cellular effects of cyclic AMP. No effects on the colony-forming potential of either control or phorbol ester-stimulated cells were observed. Similarly, the results obtained with the highly enriched population of granulocyte/macrophage colonyforming cells (31) confirmed that there was no role for CAMP in the stimulation of granulocyte/macrophage colony-forming cells proliferation, either in the presence or absence of myeloid growth factors. However, recent findings suggest that the activation of the CAMP/protein kinase A signalling pathway may be involved in the granulocyte colony-stimulating factor-mediated proliferation of murine myeloblastic NFS-60 cells, whereas interleukin-3-dependent proliferation is not mediated in this way (32). Brief exposure of the human promyelocytic leukaemia cell line HL-60 to dibutyryl-cAMP induced the cells to differentiate along a myelocytic pathway (33). Although the previous data exclude the role of cAMP/protein kinase A as the common signal associated with proliferation or macrophage development, it may represent one of the early biochemical events required for lineage-restricted development, resulting in 
the formation of mature neutrophils. The agonist-stimulated signals associated with a specific developmental response in haemopoietic progenitor cells must be different, in order to elicit distinctive lineage commitment (34).

In summary, the present study provides further information with regard to the intracellular mechanism(s) involved in phorbol ester-mediated signalling in bone marrow cells. The results from our studies clearly demonstrated the importance of phospholipase $A_{2}$ activation for the phorbol ester-mediated increase in colony forma- tion. Thus, among the different agents applied, only staurosporine, an inhibitor of protein kinase $\mathrm{C}$, and mepacrine and heparin, putative inhibitors of phospholipase $A_{2}$, were capable of abolishing the effects of phorbol ester and permitting colony formation after continuous expsoure to inhibitors.

\section{Acknowledgements}

We thank Mrs. Žaklina Čavar for exellent technical assistance and Mrs. Đurtuca Poljak-Andus for editing the manuscript. This work was supported by the Ministry for Science of the Republic of Croatia and by the Wellcome Trust.

\section{References}

1. Dexter TM, Spooncer E. Growth and differentiation in the hemopoietic system. Ann Rev Cell Biol 1987; 3:423-41.

2. Ogawa M. Differentiation and proliferation of hematopoietic stem cells. Blood 1993; 81:2844-53.

3. Lotem J, Sachs L. Regulation of normal differentiation in mouse and human myeloid leukemic cells by phorbol esters and the mechanisms of tumour promotion. Proc Natl Acad Sci USA 1979; 76:5158-62.

4. Stuart RK, Hamilton JA. Tumor-promoting phorbol esters stimulate hematopoietic colony formation in vitro. Science 1980; 208:402-4.

5. Sieber F, Stuart FK, Spivak JL. Tumor-promoting phorbol esters stimulate myelopoiesis and supress erythropoiesis in cultures of mouse bone marrow cells. Proc Natl Acad Sci USA $1981 ; 78: 4402-6$.

6. Hug $H$, Sarre TF. Protein kinase $C$ isoenzymes: divergence in signal transduction? Biochem J 1993; 291:329-43.

7. Višnjić $D$, Batinić $D$, Lasić $Z$, Knotek $M$, Marušić $M$, Banfić $\mathrm{H}$. Phorbol 12-myristate 13-acetate mediated signalling in murine bone marrow cells. Biochem J. In press.

8. Nishizuka Y. Intracellular signaling by hydrolysis of phospholipids and activation of protein kinase C. Science 1992; 258:607-14.

9. Kishimoto T, Taga T, Akira S, Cytokine signal transduction. Cell 1994; 76:253-62.

10. Metcalf D, Johnson GR, Mandel TE. Colony formation in agar by multipotential hemopoietic cells. J Cell Physiol 1979; 98:401-20.

11. Tamaoki T, Nakano H. Potent and specific inhibitors of protein kinase C of microbial origin. Biotechnology 1990; 8:732-5.

12. Somogyi L, Lasić Z, Vukičević S, Banfić H. Collagen type IV stimulates an increase in intracellular $\mathrm{Ca}^{2+}$ in pancreatic acinar cells via activation of phospholipase C. Biochem J 1994; 299:603-1.

13. Bialojan C, Takai A. Inhibitory effect of a marine-sponge toxin, okadaic acid, on protein phosphatases. Biochem J 1988; 256:283-90.

14. Heyworth CM, Dexter TM, Nicholls SE, Whetton AD. Protein kinase $C$ activators can interact synergstically with granulocyte colony-stimulating factor or interleukin- 6 to stimulate colony formation from enriched granulocyte-macrophage colonyforming cells. Blood 1993; 81:894-900.

15. Burgess AW, Nicola NA. Effects of 12-O-tetradecanoylphorbol-13-acetate (TPA) on the proliferation of granulocyte-macrophage colony-forming cells. Blood 1983; 61:575-9.

16. Gerson SL, Cooper RA. Release of granulocyte-specific colony-stimulating activity by human bone marrow exposed to phorbol esters. Blood 1984; 63:878-85.

17. McCrady CW, Li F, Pettit GR, Grant S. Modulation of the activity of a human granulocyte-macrophage colony-stimulating factor/interleukin-3 fusion protein (pIXY 321) by the macrocyclic lactone protein kinase $\mathrm{C}$ activator bryostatin 1 . Exp Hematol 1993; 21:893-900.

18. He Y, Hewlett E, Temeles D, Quesenberry P. Inhibition of interleukin 3 and colony-stimulating factor 1-stimulated marrow cell proliferation by pertussis toxin. Blood 1988; 71:1187-95.

19. Nakamura T, Lin LL, Kharbanda S, Knopf J, Kufe D. Macrophage colony stimulating factor activates phosphatidylcholine hydrolysis by cytoplasmic phospholipase $\mathrm{A}_{2}$. EMBO J 1992; 11:4917-22.

20. Whetton AD, Heyworth CM, Nicholls SE, Evans CA, Lord JM, Dexter TM, Owen-Lynch PJ. Cytokine-mediated protein kinase $C$ activation is a signal for lineage determination in bipotential granulocyte macrophage colony-forming cells. J Cell Biol 1994; 125:651-9.

21. Tsujishita Y, Asaoka Y, Nishizuka Y. Regulation of phospholipase $\mathrm{A}_{2}$ in human leukemia cell lines: its implication for intracellular signalling. Proc Natl Acad Sci USA 1994; 91:6274-8.

22. Abraham NG, Feldman E, Falck JR, Lutton JD, Schwartzman ML. Modulation of erythropoiesis by novel human bone marrow cytochrome P450-dependent metabolites of arachidonic acid. Blood 1991; 78:1461-6.

23. Kriegler AB, Bradley TR, Hodgson GS. The effect of prostaglandins $E_{1}$ and $E_{2}$ on macrophage progenitor cells with high proliferative potential in mouse bone marrow in vitro. Blood 1984; 63:1348-52.

24. Stenke L, Mansour M, Reizenstein P, Lindgren JA. Stimulation of human myolopoiesis by leukotrienes $\mathrm{B}_{4}$ and $\mathrm{C}_{4}$ : interactions with granulocyte-macrophage colony-stimulating factor. Blood 1993; 81:352-6.

25. Anafi M, Gazit A, Gilon C, Neriah Y, Levitzki A. Tyrphostininduced differentiation of mouse erythroleukemia cells. FEBS Lett 1993; 330:260-4.

26. Lyall RM, Zilberstein A, Gazit A, Gilon C, Levitzki A, Schlessinger J. Tyrophostins inhibit epidermal growth factor (EGF)receptor tyrosine kinase activity in living cells and EGF-stimulated cell proliferation. J Biol Chem 1989; 264:14503-9.

27. Bianchini L, Woodside M, Sardet C, Pouyssegur J, Takai A, Grinstein S. Okadaic acid, a phosphatase inhibitor, induces activation and phosphorylation of the $\mathrm{Na}^{+} / \mathrm{H}^{+}$antiport. $\mathrm{J}$ Biol Chem 1991; 266:15406-13.

28. Hernandez-Sotomayor SMT, Mumby M, Carpenter G. Okadaic-acid-induced hyperphosphorylation of the epidermal growth factor receptor. J Biol Chem 1991; 266:2181-6.

29. Kiss $Z$. The protein phosphatase inhibitor, okadaic acid, potentiates the stimulatory effect of phorbol ester on phosphatidylcholine synthesis, but not on phospholipid hydrolysis, in tibroblasts. FEBS Lett 1992; 308:290-2.

30. Ishida Y, Furukawa Y, Decaprio JA, Saito M, Griffin JD. Treatment of myeloid leukemic cells with the phosphatase inhibitor okadaic acid induces cell cycle arrest at either GI/S or G2/M depending on dose. J Cell Physiol 1992; 150:484-92. 
31. Cook N, Dexter TM, Lord BI, Cragoe EJ, Whetton AD. Identification of a common signal associated with cellular proliferation stimulated by four haemopoietic growth factors in a highly enriched population of granulocyte/macrophage colony-forming cells. EMBO J 1989; 8:2967-74.

32. Kobayashi K, Nishikawa M, Omay SB, Toyoda H, Deguchi K, Shirakawa S. Forskolin potentiates G-SCF-induced proliferation of a murine myeloblastic leukemia cell line. Leukemia Res 1994; 18:111-7.

33. McCachren SS, Nichols J, Kaufman RE, Niedel JE. Dibutyryl cyclic adenosine monophosphate reduces expression of c-myc during HL-60 differentiation. Blood 1986; 68:412-6.
34. Whetton $A D$, Heyworth CM, Nicholls SE, Evans CA, Lord JM; Dexter TM, Owen-Lynch PJ. Cytokine-mediated protein kinase $\mathrm{C}$ activation is a signal for lineage determination in bipotential granulocyte macrophage colony-forming cells. $\mathrm{J}$ Cell Biol 1994; 125:651 -9.

\section{Dora Višnjić}

Zavod za fiziologiju

Medicinski fakultet

Šalata 3

POB 978

41001 Zagreb

Croatia 